\title{
KAJIAN TINGKAT KEPUASAN KONSUMEN GO-FOOD DI DKI JAKARTA, DENGAN TINJAUAN PENGARUH BAURAN PROMOSI DAN KUALITAS LAYANAN
}

\author{
Sepriliani Rosanda Dewi ${ }^{1)}$ Ignatius Ario Sumbogo $^{2)}$ \\ ${ }^{1)}$ Manajemen, Fakultas Bisnis Institut Teknologi dan Bisnis Kalbis \\ Jalan Pulomas Selatan Kav. 22, Daerah Khusus Ibukota Jakarta Timur, Indonesia 13210 \\ Email $^{1)}$ : sepriliani1@gmail.com \\ ${ }^{2)}$ Manajemen, Fakultas Bisnis Institut Teknologi dan Bisnis Kalbis \\ Jalan Pulomas Selatan Kav. 22, Daerah Khusus Ibukota Jakarta Timur, Indonesia 13210 \\ Email $^{2)}$ :ignatius.sumbogo@kalbis.ac.id
}

\begin{abstract}
ABSTRAK:
Penelitian ini bertujuan untuk mengetahui pengaruh bauran promosi dan kualitas layanan terhadap meningkatnya kepuasan konsumen Go-Food. Unit Analisis yang diamati adalah konsumen Go-Food di area DKI Jakarta. Penelitian ini menggunakan pendekatan deskriptif kuantitatif dengan teknik pengumpulan data adalah teknik survey menggunakan instrumen kuesioner kepada 206 responden yang disebarkan melalui google form. Metode analisis data menggunakan regresi linear berganda dengan software SPSS ver. 24. Dari hasil analisis, diketahui bahwa bauran promosi berpengaruh signifikan terhadap kepuasan konsumen, kualitas layanan berpengaruh signifikan terhadap kepuasan konsumen, serta bauran promosi dan kualitas layanan berpengaruh signifikan terhadap kepuasan konsumen. Pada analisis indikator diketahui, Go-Food harus lebih meningkatkan kualitas pelayanan pada konsumen dan juga meningkatkan promosi di platform media sosial.
\end{abstract}

Kata kunci: bauran promosi, kualitas layanan, kepuasan konsumen.

\begin{abstract}
:
This study is structured in order to determine the effect of promotion mix and service quality on increasing customer satisfaction of Go-Food. The unit of analysis observed was Go-Food consumers in the DKI Jakarta area. This study uses a quantitative descriptive approach with data collection techniques is a survey technique using a questionnaire instrument to 206 respondents, distributed through the google form. Data analysis method uses multiple linear regression with SPSS software ver. 24. The results of the analysis show that the promotion mix has a significant effect on consumer satisfaction, service quality has a significant effect on customer satisfaction, while the promotion mix and service quality simultaneously have a significant effect on customer satisfaction. In the analysis of indicators known, Go-Food must further improve the quality of service to consumers and also increase promotion on social media platforms.
\end{abstract}

Keywords: promotion mix, service quality, customer satisfaction. 


\section{National Conference of Creative Industry: \\ Sustainable Tourism Industry for Economic Development}

Universitas Bunda Mulia, Jakarta, 5-6 September 2018

e-ISSN No: 2622-7436

\section{PENDAHULUAN}

Era globalisasi yang diikuti dengan perkembangan ilmu pengetahuan dan teknologi menjadi gambaran bagaimana kemajuan suatu peradaban. Iptek menjadi krusial, yakni kunci utama dalam pembangunan ekonomi suatu negara dan menjadi kekuatan utama dalam persaingan global. Hal tersebut menuntut kemampuan Negara dan komunitas masyarakat untuk memberikan respon atas perubahan ke arah yang lebih praktis. Negara-negara maju di Asia seperti Jepang, Korea Selatan dan Taiwan konsisten mengerahkan sejumlah besar dana untuk para ilmuwan sehingga mampu berlomba dalam kompetisi penguasaan Iptek, dimana terminal akhirnya adalah inovasi demi inovasi yang dapat diaplikasikan dalam dunia industry, yakni untuk meningkatkan daya saing produk dan meraup devisa hingga ujungnya mengangkat kualitas hidup dan kesajahteraan masyarakat.

Proses perubahan dunia yang semakin teknologis ini dinamakan era digital globalisasi yang ditandai dengan akselerasi proses globalisasi oleh Iptek. Hadirnya ekonomi digital menjawab tantangan bagi sektor ekonomi mikro atau usaha yang baru start up untuk ikut bersaing dalam pangsa pasar global. Seperti yang telah disinggung sebelumnya, kontribusi aspek digital terhadap perekonomian secara global cenderung meningkat. Mengutip penelitian Mc. Kinsey Global Institute tahun 2016, dalam satu dekade terakhir ekonomi digital telah menyumbang sekitar $10 \%$ dari Produk Domestik Bruto (PDB) dunia. Adapun nilainya mencapai sekitar 7,8 triliun dollar AS.

Perkembangan ekonomi digital juga ikut menjadi tren di Indonesia. Bahkan, Indonesia diprediksi menjadi negara dengan ekonomi digital terbesar di Asia Tenggara. Dari data analisis Ernst dan Young, dapat dilihat pertumbuhan nilai penjualan bisnis online di Indonesia setiap tahun meningkat $40 \%$. Menteri Koordinator Bidang Perekonomian Darmin Nasution menyatakan, produk ekonomi digital Indonesia berpusat pada e-commerce dan fintech (financial technology). Potensi industri e-commerce di Indonesia memang tidak dapat dipandang sebelah mata. Berikut pemetaan e-commerce Indonesia dari situs pencarian seperti aplikasi langsung, twitter, facebook dan juga karyawan berdasarkan hasil penelitian yang dilakukan iPrice.

\begin{tabular}{|c|c|c|c|c|c|c|}
\hline Rank & Visits & App Installs & Twitter & Instagram & Facabook & Employes: \\
\hline 1 & Lazada & Ali Express & Blibli & Hijup & Lazada & Mapemall \\
\hline 2 & Tokopedia & Zalora & Tokopedia & Shopee & Zalora & Lazada \\
\hline 3 & Elevenia & Tokopedia & Lazada & Lazada & Blibli & Tokopedia \\
\hline 4 & Bukalapak & Lazada & Bukupedia & 8Wood & Tokopedia & Bukalapak \\
\hline 5 & BliBli & Shopee & Elevenia & Mothercare & Shopee & Mataharimall \\
\hline 6 & JDID & Bukalapak & Bukalapak & Brodo & Bukalapak & Blibli \\
\hline 7 & Shopee & Mataharimall & Matahari Mall & Tokopedia & Mataharimall & Shopee \\
\hline 8 & Blanja & Q0010 & Bhinneka & Mataharimall & Elevenia & Bhinneka \\
\hline 9 & Matahari Mall & Blibli & Zalora & Zalora & Brodo & Zalora \\
\hline 10 & Bhinneka & Elevenia & Hijup & Bukalapak & Bhinneka & Elevenia \\
\hline
\end{tabular}

Gambar 1 Top 10 E-commerce

Sumber : IPrice (Eka, 2017)

Riset Google bersama A.T. Kearney yang dirilis pada September 2017 menunjukkan nilai investasi di perusahaan-perusahaan rintisan berbasis digital menyentuh angka Rp 40 triliun sampai semester pertama. Angka itu melompati 
nilai investasi sektor makanan dan minuman. Investasi lokal dan global pada perusahaan rintisan hanya kalah dibanding kucuran modal ke sektor pertambangan serta minyak dan gas bumi. Seperti yang dapat dilihat pada diagram berikut:

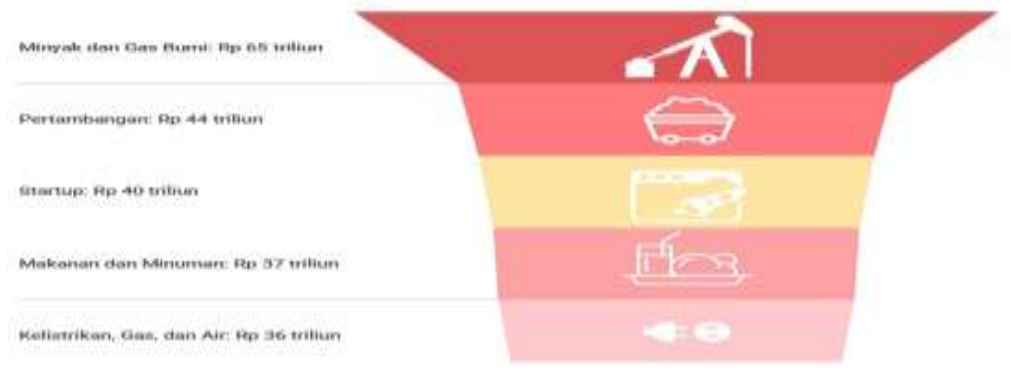

Gambar 2 Investasi Digital Sektor Lain (kuartal 1 2017, Rp triliun)

Sumber: Tempo (Hamid, 2018)

Khusus pada tahun 2018, financial technology dan industri kesehatan menempati puncak ekonomi digital Indonesia. Preferensi investor tersebut didapat Google dan A.T. Kearney dari survei mereka terhadap puluhan pemodal, baik personal maupun institusional, lokal dan global. Berikut diagram nilai transaksi ekonomi digital tahun 2017 dan prediksi untuk tahun 2022.

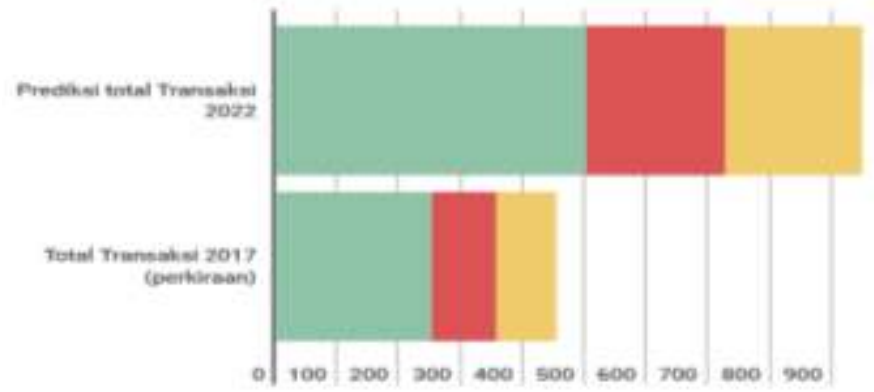

Gambar 3 Nilai Transaksi Ekonomi Digital

Sumber: Tempo (Hamid, 2018)

Perkembangan ekonomi digital juga dimanfaatkan dalam sektor transportasi. Saat ini, transportasi umum berbasis aplikasi atau online membawa dampak yang cukup besar bagi perekonomian Indonesia dan membantu aktivitas masyarakat dengan adanya transportasi online, dengan alasan cepat dan efisien. Salah satu yang berkembang pesat adalah Gojek. Gojek Indonesia mulai melebarkan bisnisnya di bidang kuliner, yaitu Go-Food. Go-Food merupakan sebuah fitur layanan food delivery layaknya delivery order di sebuah rumah makan. Hanya dengan menggunakan smartphone dan membuka fitur Go-Food di dalam aplikasi Gojek, konsumen bisa memesan makanan dari restoran yang sudah bekerja sama dengan Gojek. Makanan akan dipesan dan diantar langsung oleh Gojek. Bagi pengusaha kuliner, terutama Usaha Mikro, Kecil, dan Menengah (UMKM) yang memiliki budget terbatas untuk mengembangkan layanan delivery order, Go-Food bisa menjadi solusi alternatif yang sangat membantu. Pengusaha UMKM bisa memiliki layanan delivery order tanpa harus menyiapkan armada. 


\section{National Conference of Creative Industry: \\ Sustainable Tourism Industry for Economic Development}

Universitas Bunda Mulia, Jakarta, 5-6 September 2018

e-ISSN No: 2622-7436

Layanan Go-food memang langsung mendapat sambutan positif dari para pelaku pengusaha kuliner (Avin, 2018). Bahkan menurut keterangan dari pihak Gojek pada April 2015, layanan Go-Food sudah bekerja sama dengan 15 ribu tempat makan di wilayah Jabodetabek. 15 ribu tempat makan tersebut terdiri dari 23 kategori, mulai dari kaki lima hingga restoran mewah. Go-food sering memberikan potongan harga, promosi, voucher kepada para konsumen. Promo Go-Food voucher berlaku untuk jutaan pelanggan Go-Food yang berada di 11 kota di Indonesia, yaitu Surabaya, Medan, Yogyakarta, Makassar, Bandung, Semarang, Palembang, Bali, Solo, Malang, dan Jabodetabek. Fenomena ini diafirmasi oleh penelitian yang dilakukan Arif (2017), Dianti (2017) dan Hartatik (2017), bahwa Promosi, Harga, dan Kualitas Pelayanan memiliki pengaruh positif yang signifikan terhadap Keputusan Penggunaan Jasa Go-Jek, terhadap Kepuasan Pelanggan dan Loyalitas Konsumen terhadap Transportasi Online Go-Jek.

Di sisi lain, masih banyak layanan pesan antar mengabaikan standar ideal pengiriman makanan. Pengemudi banyak tak dilengkapi dengan kotak khusus penyimpan makanan. Mereka lazim hanya menggantung makanan yang dipesan pada sisi motor. Belum lagi, jarak pemesanan bisa mencapai $25 \mathrm{~km}$ jauhnya. Kondisi tersebut berisiko menyebabkan masalah pada kualitas makanan. Prof. Dr. Ir. Nuri Andarwulan, Direktur Southeast Asian Food \& Agricultural Science \& Technology (SEAFEST) mengatakan jarak yang terlalu jauh dapat menurunkan kualitas makanan karena pengemudi menghabiskan waktu lebih lama untuk mengantarkan makanan ke rumah pelanggan. Selain itu, layanan Go-food sering kali dihadapkan dengan keluhan konsumen karena kesalahan teknis. Seperti awal tahun 2018 yang baru-baru ini terjadi, konsumen mengeluhkan aplikasi Gojek karena sulit diakses. Bahkan banyak juga yang melaporkan aplikasi Gojek tibatiba log out sendiri. Sementara itu, ada juga keluhan lain yang menyatakan bahwa aplikasi Go-Jek di $i O S$ tiba-tiba log out dan pengguna tidak bisa masuk kembali.

Berdasarkan uraian di atas, permasalahan dalam penelitian ini dapat di uraikan sebagai berikut: Apakah bauran promosi memiliki pengaruh signifikan terhadap meningkatnya kepuasan konsumen Go-food? Apakah kualitas layanan memiliki pengaruh signifikan terhadap meningkatnya kepuasan konsumen Gofood? Apakah bauran promosi dan kualitas layanan memiliki pengaruh signifikan terhadap meningkatnya kepuasan konsumen Go-food? Tujuan yang akan di penuhi dalam penelitian ini adalah sebagai berikut: untuk mengetahui dan menganalisis apakah bauran promosi memiliki pengaruh yang signifikan terhadap kepuasan konsumen Go-food, untuk mengetahui dan menganalisis apakah bauran promosi memiliki pengaruh yang signifikan terhadap kepuasan konsumen Gofood, dan untuk mengetahui dan menganalisis apakah bauran promosi dan kualitas layanan secara bersama-sama memiliki pengaruh yang signifikan terhadap kepuasan konsumen Go-food.

\section{TINJAUAN PUSTAKA \\ Bauran Promosi}

Bauran promosi merupakan alat komunikasi yang terdiri dari kombinasi alat-alat promosi yang digunakan oleh perusahaan. Pada umumnya alat-alat promosi tersebut memiliki hubungan yang erat, sehingga diantaranya tidak dapat 
dipisahkan, karena bersifat saling mendukung dan melengkapi. Kotler dan Armstrong (2012:432) mengemukakan, "Promotion mix (marketing communications mix) is the specific blend of promotion tools that the company uses to persuasively communicate customer value and build customer relationships", yang artinya bauran promosi (bauran komunikasi pemasaran) adalah campuran spesifik dari alat-alat promosi yang digunakan perusahaan untuk secara persuasif mengomunikasikan nilai pelanggan dan membangun hubungan pelanggan.

Kualitas pelayanan merupakan salah satu bagian dari strategi Manajemen Pemasaran. Kualitas pelayanan telah menjadi satu tahap faktor dominan terhadap keberhasilan suatu organisasi. Pengembangan kualitas sangat didorong oleh kondisi persaingan antar perusahaan, kemajuan teknologi, tahapan perekonomian dan sosial budaya masyarakat. Menurut Tjiptono (2011:59) menyatakan bahwa “ Kualitas layanan adalah tingkat keunggulan yang diharapkaan dan pengendalian atas tingkat keunggulan tersebut untuk memenuhi keinginan pelanggan".Menurut Goeth dan Davis yang dikutip Tjiptono (2012:51) menyatakan bahwa "Kualitas layanan merupakan suatu kondisi dinamis yang berhubungan dengan produk, jasa, proses, dan lingkungan yang memenuhi atau melebihi harapan".

Menurut Kotler dan Keller (2009:138) kepuasan (satisfication) adalah perasaan senang atau kecewa seseorang yang timbul karena membandingkan kinerja yang dipersepsikan produk atau hasil terhadap ekspetasi mereka. Kepuasan konsumen diartikan sebagai suatu keadaan dimana harapan konsumen terhadap suatu produk sesuai dengan kenyataan yang diterima oleh konsumen. Jika produk tersebut jauh dibawah harapan, konsumen akan kecewa. Sebaliknya, jika produk tersebut memenuhi harapan, konsumen akan puas. Harapan konsumen dapat diketahui dari pengalaman mereka sendiri saat menggunakan produk tersebut, informasi dari orang lain dan informasi yang diperoleh dari iklan atau promosi yang lain (Kotler dalam Sopiah Sangadji, 2013:181)

\section{Model Konseptual Penelitian}

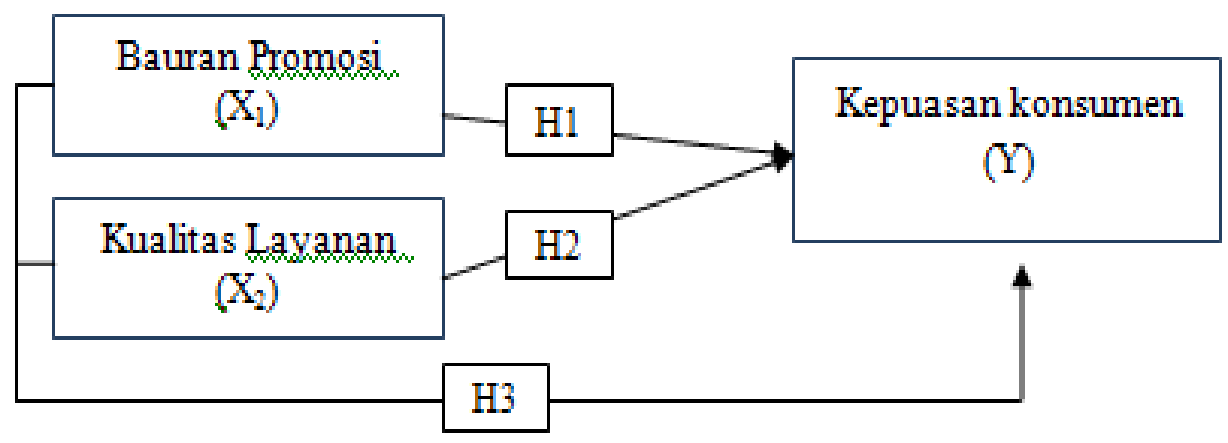

Gambar 4 Model Konseptual Penelitian

Berdasarkan Gambar 2.1 model konseptual penelitian di atas, dapat dirumuskan hipotesis. Hipotesis yang dirumuskan dalam penelitian ini adalah sebagai berikut: (H1) Bauran promosi memiliki pengaruh yang signifikan terhadap kepuasan 


\section{National Conference of Creative Industry: \\ Sustainable Tourism Industry for Economic Development}

Universitas Bunda Mulia, Jakarta, 5-6 September 2018 e-ISSN No: 2622-7436

konsumen Go-food, (H2) Kualitas layanan memiliki pengaruh yang signifikan terhadap kepuasan konsumen Go-food, dan (H3) Bauran promosi dan kualitas layanan secara bersama-sama berpengaruh signifikan terhadap kepuasan konsumen Go-food.

\section{Hubungan Antar Variabel}

Bauran promosi merupakan alat komunikasi yang terdiri dari kombinasi alat-alat promosi yang digunakan oleh perusahaan. Pada umunya alat-alat promosi tersebut memiliki hubungan yang erat, sehingga diantaranya tidak dapat dipisahkan, karena bersifat salling mendukung dan melengkapi. Penelitian sebelumnya mengatakan bahwa variabel bauran promosi berpengaruh positif dan signifikan terhadap kepuasan konsumen (Sulaiman 2012:64). Sehingga terbukti bahwa secara simultan ada pengaruh antara variabel bebas (Personal Selling, Mas Selling, dan Promosi penjualan) terhadap variabel terikat penjualan.

Kualitas pelayanan merupakan salah satu bagian dari strategi manajemen pemasaran. Kualitas pelayanan telah menjadi satu tahap faktor dominan terhadap kenerhasilan suatu organisasi, pengembangan kualitas sangat didorong oleh kondisi persaingan antar perusahaan, kemajuan teknologi, tahapan perekonomian dan sosial budaya masyarakat. Menurut Tjiptono (2011:59) mengatakan bahwa kualitas layanan adalah tingkat keunggulan yang diharapkan dan pengendalian atas tingkat keunggulan tersebut untuk memenuhi keingginan pelanggan. Penelitian sebelumnya Khusaini (2016:57) kualitas pelayanan berpengaruh terhadap kepuasan kepuasan konsumen di Spa Club arena Yogyakarta untuk meningkatkan kualitas dari faktor-faktor tersebut.

Penelitian sebelumnya Lontoh (2016:6) mengatakan bahwa variabel bauran promosi berpengaruh positif dan signifikan terhadap kepuasan konsumen bauran promosi secara keseluruhan bersama-sama diduga berpengaruh positif dan signifikan terhadap kepuasan konsumen pada PT. Hasjrat Abadi Manado Cabang Tendean. Serta penelitian selanjutnya Zakaria (2017:8) mengatakan bahwa variabel kualitas layanan berpengaruh positif dan signifikan terhadap kepuasan pelanggan pengguna jasa transportasi taksi Bluebird di Surabaya.

\section{METODE PENELITIAN Jenis Penelitian}

Penelitian ini menggunakan metode kuantitatif, yaitu yang menurut Sugiyono, (2012:23) dikatakan metode kuantitatif karena data penelitian berupa angka-angka dan analisis menggunakan statistik. Penelitian kuantitatif menekankan pada pengujian teori-teori melalui pengukuran variabel-variabel penelitian dengan angka dan melakukan analisis data dengan prosedur statistik (Indriantoro \& Supomo, 2012:12). Variabel yang diteliti dalam penelitian ini yaitu bauran promosi dan kualitas layanan sebagai variabel independen (variabel bebas) dan kepuasan konsumen sebagai variabel dependen (variabel terikat).

\section{Metode Pengumpulan Data}

Penelitian kuantitatif menekankan pada pengujian teori-teori melalui pengukuran variabel-variabel penelitian dengan angka dan melakukan analisis 
data dengan prosedur statistik (Indriantoro, 2012:12). Dengan demikian peneliti menggunakan data kuantitatif dari hasil penyebaran kuesioner yang berupa selembaran kertas yang secara langsung diberikan kepada responden dengan menyediakan pertanyaan-pertanyaan yang dapat dijawab oleh responden.

Sumber data yang digunakan dalam penelitian ini adalah sumber data primer dan sumber data sekunder. Data Primer, menurut Sugiyono (2012:139), adalah sebagai sumber data yang langsung memberikan data kepada pengumpulan data. Pengumpulan data primer dalam penelitian ini melalui cara menyebarkan kuesioner melalui Google form, sumber data primer dalam penelitian ini diperoleh dari hasil penyebaran kuesioner. Sementara Data Sekunder, menurut Sugiyono (2012:141), adalah sebagai sumber data yang diperoleh dengan cara membaca, mempelajari dan memahami melalui media lain yang bersumber dari literatur, buku-buku, serta dokumen perusahaan.

Metode pengumpulan data dalam penelitian ini menggunakan dua metode yaitu melalui studi lapangan dan studi kepustakaan, yaitu: 1) Studi Lapangan, yakni peneliti melakukan studi lapangan melalui survei dengan teknik menyebarkan kuesioner secara langsung kepada subjek penelitian. Kuesioner atau angket merupakan alat pengumpulan data yang memuat sejumlah pertanyaan atau pernyataan yang harus dijawab oleh subjek penelitian (Mulyatiningsih, 2012:28). Kuesioner yang digunakan dalam penelitian ini yaitu dengan instrumen Skala Likert yang diberi skor interval 1 - 5 dengan jawaban sangat tidak setuju, tidak setuju, netral, setuju, sangat setuju. Dan, 2) Studi Kepustakaan, yaitu proses yang dilakukan untuk mendapatkan data sekunder dengan sumber data yang diperoleh dari sumber buku, jurnal, penelitian terdahulu. Data sekunder ini dapat menjadi data pendukung untuk data primer yang diperoleh dari hasil kuesioner.

\section{Populasi}

Menurut Sugiyono (2012:61) populasi adalah wilayah generalisasi yang terdiri atas: obyek atau subyek yang mempunyai kuantitas dan karakteristik tertentu yang ditetapkan oleh peneliti untuk dipelajari dan kemudian ditarik kesimpulannya. Di dalam penelitian ini populasi yang digunakan adalah konsumen Go-food, secara spesifik keseluruhan konsumen yang telah menginstal aplikasi Gojek dan menggunakan aplikasi Go-food.

\section{Sampel}

Menurut Sugiyono (2012:62) sampel adalah bagian dari jumlah dan karakteristik yang dimiliki oleh populasi. Bila populasi besar, dan peneliti tidak mungkin mempelajari semua yang ada pada popuasi, misalnya karena keterbatasan dana, tenaga dan waktu. Maka peneliti dapat menggunakan sampel yang diambil dari populasi. Dalam penelitian ini tidak ditemukan data populasi konsumen Go-food dalam menentukan jumlah sampel, penelitian ini menggunakan teori menurut Malhotra (2010), dimana dijelaskan jika populasi tidak diketahui, maka sampel dapat diambil dengan menghitung jumlah pertanyaan (n) dikali lima. Keseluruhan pertanyaan dalam penelitian ini berjumlah 32 pernyataan sehingga $=32 \times 5=160$. Jadi, jumlah sampel yang diperoleh adalah sebanyak 160 sampel. Tetapi, dalam penelitian ini, penelilti bermaksud 
untuk lebih maksimal dalam menguji instrument dan model, maka peneliti menambahkan jumlah 47 sampel sehingga total sampel menjadi 207 responden.

\section{HASIL PENELITIAN DAN PEMBAHASAN}

\section{Uji Instrumen}

\section{A. Uji Validitas}

Suatu kuesioner dapat dikatakan valid jika setiap pernyataan-pernyataan yang diberikan responden dapat memberikan suatu pengukuran oleh kuesioner tersebut. Metode yang digunakan untuk mengukur validitas dengan cara mengkorelasikan total skor masing-masing pernyataan dengan menggunakan rumus teknik korelasi product moment. Dengan nilai $\mathrm{DF}=\mathrm{n}-2=207-2=205$ dan tingkat signifikansinya 5\%, maka dihasilkan nilai $r$ tabelnya sebesar 0,136

\section{Tabel 1 Koefisien Validitas Variabel Bauran Pemasaran}

\begin{tabular}{|c|c|c|c|c|}
\hline Dimensi & $\begin{array}{c}\text { Item } \\
\text { Pertanyaan }\end{array}$ & $\begin{array}{c}\text { Total Pearson } \\
\text { Correlation }\end{array}$ & $\begin{array}{c}\text { Nilai } r \text { Tabel } \\
D f=n-2=207-2=205\end{array}$ & Keterangan \\
\hline & $B P 1$ & 0.669 & 0,136 & Valid \\
\hline & $B P 2$ & 0.639 & 0,136 & Valid \\
\hline & $B P 3$ & 0.632 & 0,136 & Valid \\
\hline & BP4 & 0.585 & 0,136 & Valid \\
\hline & BP5 & 0.622 & 0,136 & Valid \\
\hline & BP6 & 0.656 & 0,136 & Valid \\
\hline Bauran & $B P 7$ & 0.581 & 0,136 & Valid \\
\hline \multirow[t]{10}{*}{ Promosi } & $B P 8$ & 0.610 & 0,136 & Valid \\
\hline & $B P 9$ & 0.693 & 0,136 & Valid \\
\hline & $B P 10$ & 0.742 & 0,136 & Valid \\
\hline & $B P 11$ & 0.732 & 0.136 & Valid \\
\hline & $B P 12$ & 0.657 & 0.136 & Valid \\
\hline & $B P 13$ & 0.705 & 0,136 & Valid \\
\hline & $B P 14$ & 0.682 & 0.136 & Valid \\
\hline & $B P 15$ & 0.623 & 0.136 & Valid \\
\hline & $B P 16$ & 0.591 & 0.136 & Valid \\
\hline & $B P 17$ & 0.639 & 0.136 & Valid \\
\hline
\end{tabular}

Sumber: Pengolahan data mengunakan SPSS 24

Dari Tabel 1 terbukti bahwa instrumen kuesioner variabel bauran promosi memiliki hasil yang valid dikarenakan nilai korelasi person yang lebih besar dibanding dengan nilai tabel $r$, yaitu sebesar 0,136. Sementara untuk instrumen Variabel kualitas layanan adalah sebagai berikut:

Tabel 2 Koefisien Validitas Variabel Kualitas Layanan 


\begin{tabular}{|c|c|c|c|c|}
\hline Dimensi & $\begin{array}{c}\text { ltem } \\
\text { Pertanyaan }\end{array}$ & $\begin{array}{c}\text { Toral Pearson } \\
\text { Correlation }\end{array}$ & $\begin{array}{c}\text { Nilair Tabel } \\
D f=n-2=207-2=205\end{array}$ & Keterangan \\
\hline \multirow{11}{*}{$\begin{array}{l}\text { Kualtas } \\
\text { Layanan }\end{array}$} & KL1 & 0775 & 0,136 & Valid \\
\hline & $\mathrm{KL2}$ & 0.823 & 0,136 & Valid \\
\hline & $K L 3$ & 0.007 & 0,136 & Valid \\
\hline & KL4 & 0.001 & 0,136 & Valid \\
\hline & $K L 5$ & 0.823 & 0,136 & Valo \\
\hline & KLE & 0744 & 0,136 & Valió \\
\hline & $\mathrm{RL7}$ & 6839 & 0,136 & Vald \\
\hline & KLB & 0.774 & 0,136 & Vaid \\
\hline & KL9 & 0729 & 0,136 & Valió \\
\hline & KL10 & 0649 & 0,136 & Vald \\
\hline & KL11 & 0.490 & 0.136 & Valio \\
\hline
\end{tabular}

Sumber: Pengolahan data mengunakan SPSS 24

Dari Tabel 2 terlihat $r$ hitung instrumen memiliki hasil yang valid dikarenakan nilai korelasi person yang lebih besar dibanding dengan nilai $\mathrm{r}$ tabel 0,136 . Sementara untuk instrumen Variabel Kepuasan konsumen adalah sebagai berikut:

\section{Tabel 3 Koefisien Validitas Variabel Kepuasan Konsumen}

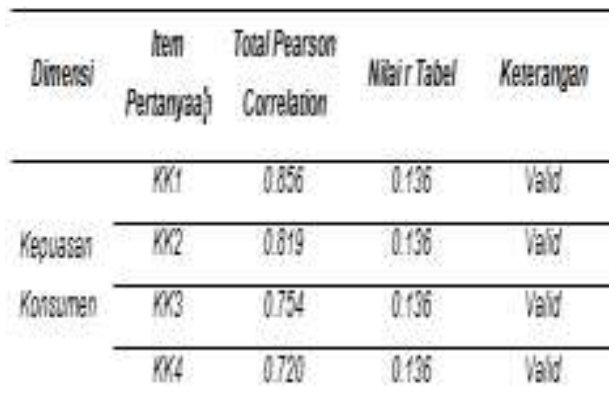

Sumber: Pengolahan data mengunakan SPSS 24

Dari Tabel 3 terlihat instrumen memiliki hasil yang valid dikarenakan nilai korelasi person yang lebih besar dibanding dengan nilai $r$ tabel 0,136.

\section{B. Uji Realibilitas}

Realibilitas menunjukan pada suatu pengertian bahwa sesuatu instrumen cukup dapat dipercaya untuk digunakan sebagai alat pengumpul data karena instrumen tersebut sudah baik (Sunyoto, 2011:70) Instrumen yang baik tidak akan bersifat tendensius mengarahkan responden untuk memilih jawaban-jawaban tertentu. Instrumen yang sudah dapat dipercaya, yang reliabel akan menghasilkan data yang dapat dipercaya juga, apabila data sudah bener sesuai dengan kenyataan nya, maka berapa kalipun diambil tetap akan sama. Butir kuesioner dapat dikatakan reliabel apabila nilai Cronbach's Alpha >0,60.

Tabel 4 Hasil Uji Reliabilitas 


\begin{tabular}{lccc}
\multicolumn{1}{c}{ Dimensi } & Cronbach Alpha & N of Items & Keterangan \\
\hline Bauran Promosi & 0.912 & 17 & Reliabel \\
\hline Kualitas Layanan & 0.921 & 11 & Reliabel \\
\hline $\begin{array}{l}\text { Kepuasan } \\
\text { Konsumen }\end{array}$ & 0.786 & 4 & Reliabel
\end{tabular}

Sumber: Pengolahan data mengunakan SPSS 24

Dari hasil uji realibilitas pada Tabel 3.4 diatas, maka dapat dilihat bahwa butir pernyataan memiliki hasil reliabel, berdasarkan tabel di atas dapat disimpulkan bahwa nilai reliabilitas untuk variabel bauran promosi adalah 0,912 , untuk variabel kualitas layanan adalah 0,921 , dan untuk variabel kepuasan konsumen adalah 0,786 yang berarti semuanya lebih besar dari nilai Cronbach's Alpha0,6 $(0,786>0,6$, maka dapat dinyatakan bahwa instrumen alat ukur adalah reliabel.

\section{Uji Asumsi Klasik}

\section{A. Uji Normalitas}

Uji Normalitas bertujuan untuk mengetahui apakah di dalam model regresi ada persamaan yang dihasilkan, berdistribusi normal atau berdistribusi tidak normal. Persamaan regresi dikatakan baik jika mempunyai data variabel bebas data variabel terikat berdistribusi mendekati normal atau normal sama sekali. Untuk melihat normal atau tidaknya dari setiap variabel tersebut makan digunakan bantuan program SPSS versi 24.

\section{Tabel 5 Koefisien Normalitas}

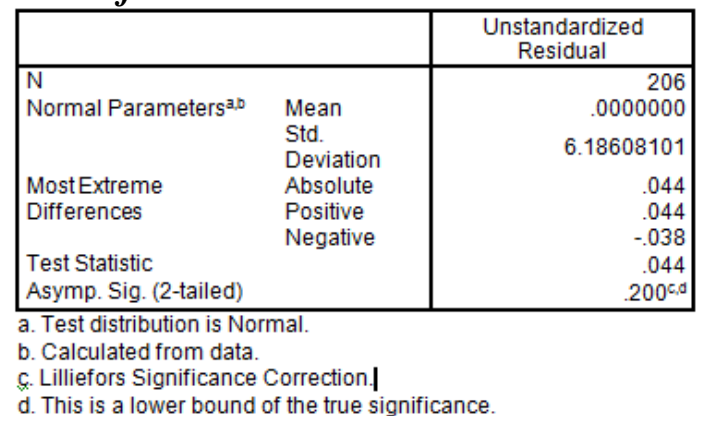

Sumber: Pengolahan data mengunakan SPSS 24

Berdasarkan Tabel 5 didapatkan hasil pengujian dengan metode One-Sample Kolmogorov-Smirnov (K-S) melihat pada Asymp. Sig. (2-tailed) menunjukkan variabel bauran promosi, kualitas layanan dan kepuasan konsumen memenuhi dasar keputusan berdistribusi normal, dinyatakan hasil Asymp. Sig 0.200 atau lebih besar dari 0,05 .

\section{B. Uji Multikolinearitas}

Uji multikolinearitas juga bertujuan untuk mengetahui apakah model regresi dengan variabel bebas ditemukan adanya korelasi. Model regresi yang baik seharusnya tidak terjadi atara variabel bebas. Untuk mendeteksi ada atau tidaknya 
multikolinearitas di dalam model regresi dapat di liat melalui nilai tolerance < 0,10 dan lawanya variance inflationfactor $(V I F>10)$. Untuk melihat hasilnya pada uji multikolonieritas dapat dilakukan dengan bantuan SPSS versi 24 dengan memilih analyze lalu regression dan linier.

Tabel 6 Hasil Uji Multikolinearitas

\begin{tabular}{|l|l|c|}
\hline \multirow{2}{*}{ Model } & \multicolumn{2}{|c|}{ Collinearity Statistics } \\
\cline { 2 - 3 } & Tolerance & VIF \\
\hline 1 (Constant) & & \\
X1 & .549 & 1.821 \\
X2 & .549 & 1.821 \\
\hline
\end{tabular}

Sumber: Pengolahan data mengunakan SPSS 24

Berdasarkan Tabel 6 diketahui nilai VIF $(1.821<10)$ dan tolerance $(0.612>$ $0,10)$. Dengan demikian dapat disimpulkan bahwa tidak ada multikolinearitas di antara variabel bebas.

\section{Uji Heteroskedastisitas}

Hasil uji heterokedastisitas bertujuan untuk menguji apakah dalam model regresi terjadi ketidaksamaan variance dari resudal satu pengamatan ke pengamatan lain. Dalam peneliti ini akan dilakukan uji statistik untuk menjamin keakuran hasil pengujian. Uji statistik yang dipilih adalah uji Rank Spearman, dasar dalam pengambilan keputusan uji heterokedastisitas melalui Uji Rank Spearman adalah sebagai berikut:

1. Apabila sig.2-tailed $<\alpha=0.05$, maka telah terjadi heterokedastisitas

2. Apabila sig.2-tailed $>\alpha=0.05$, maka tidak terjadi heterokedastisitas

\section{Tabel 7 hasil Uji Heterokedastisitas}

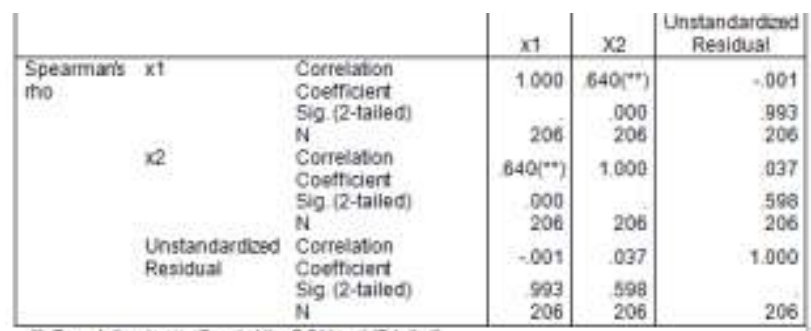

Sumber: Pengolahan data mengunakan SPSS 24

Tabel 7, menggunakan metode Rank Spearman, menunjukkan bahwa nilai Sig. (2tailed) dari setiap variabel tersebut $>0,05$. Hal ini dapat disimpulkan bahwa model regresi linear berganda terbebas dari heteroskedastisitas.

\section{Uji Regresi Linear Berganda}

Uji regresi linier berganda untuk mengetahui besaran pengaruh variabel bebas (X1 dan X2) terhadap variabel terikat (Y). Pengujian tersebut dilakukan dengan menggunakan program SPSS versi 24 dengan menu analyze lalu regression dan linear. 
Tabel 8 Koefisien Regresi

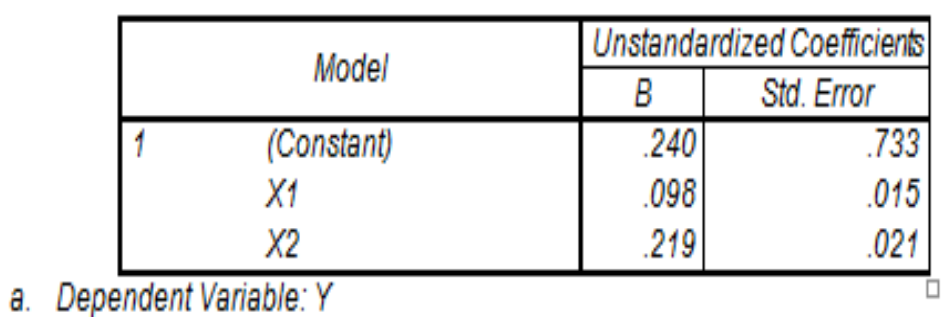

Sumber: Pengolahan data mengunakan SPSS 24

Persamaan Struktural adalah sebagai berikut:

$\mathrm{Y}=0,240+0,098 . \mathrm{X}_{1}+0,219 . \mathrm{X}_{2}+\mathrm{e}$

Keterangan sebagai berikut:

1. Persamaan Regresi $Y=0,240+0,098(X 1)+0,219(X 2)$

2. Konstanta sebesar 0,240 menyatakan bahwa: Jika variabel bauran promosi (X1) dan kualitas layanan (X2) bernilai 0, maka nilai variabel kepuasan konsumen (Y) adalah 0,240.

3. Koefisien regresi variabel bauran promosi (X1) sebesar 0,098 artinya jika variabel independen lain nilainya tetap dan bauran promosi mengalami kenaikan 1, maka variabel kepuasan konsumen (Y) akan mengalami kenaikan sebesar 0,098. Koefisien bernilai positif artinya terjadi hubungan positif antara bauran promosi dengan kepuasan konsumen, semakin naik bauran promosi maka semakin meningkat kepuasan konsumen.

4. Koefisien regresi variabel bauran promosi (X2) sebesar 0,219 artinya jika variabel independen lain nilainya tetap dan kualitas layanan mengalami kenaikan 1, maka variabel kepuasan konsumen (Y) akan mengalami kenaikan sebesar 0,219. Koefisien bernilai positif artinya terjadi hubungan positif antara kualitas layanan dengan kepuasan konsumen semakin naik kualitas layanan maka semakin meningkat kepuasan konsumen

\section{Uji Hipotesis}

Uji t digunakan untuk mengetahui ada tidaknya hubungan atau pengaruh yang berarti (signifikan) antara variabel independen (Bauran Promosi, Kualitas Layanan) secara parsial terhadap variabel dependen (Kepuasan Konsumen) Pengujian tersebut membandingkan antara $t$ hitung dan $t$ kritis. Menurut Priyanto (2009:50-51) t kritis dapat dicari pada tabel statistik pada signifikasi 0.05 dengan $\mathrm{df}=\mathrm{n}-\mathrm{k}-1$ atau 207-2-1 = 204. Kemudian dimasukan ke dalam rumus $=\operatorname{TINV}(0.05,204)=1.97166$. Menunjukan bahwa $\mathrm{t}$ kritis adalah 1,966884. Hasil dari uji t variabel bebas (X1 dan X2). Pengukurannya sebagai berikut :

1. Jika $\mathrm{t}$ hitung $\leq \mathrm{t}$ kritis $=\mathrm{H}_{0}$ diterima, $\mathrm{H}_{\mathrm{a}}$ ditolak

2. Jika t hitung $>\mathrm{t}$ kritis $=\mathrm{H}_{0}$ ditolak, $\mathrm{H}_{\mathrm{a}}$ diterima

Tabel 9 Hasil Uji Hipotesis 


\begin{tabular}{|l|r|r|}
\hline \multicolumn{1}{|c|}{ Model } & \multicolumn{1}{|c|}{$t$} & Sig. \\
\hline 1 (Constant & .327 & .744 \\
$X 1$ & 6.745 & .000 \\
$X 2$ & 10.531 & .000 \\
\hline \multicolumn{2}{|c|}{ Dependent Variable: $Y$} \\
\hline
\end{tabular}

Sumber: Pengolahan data mengunakan SPSS 24 
Berdasarkan hasil pada Tabel 9 diperoleh hasil sebagai berikut:

1. Pada variabel bauran promosi didapatkan $t$ hitung (6.745) $>t$ kritis (1.971) maka keputusannya adalah $\mathrm{Ho}_{1}$ ditolak dan $\mathrm{Ha}_{1}$ diterima, artinya bahwa secara parsial terdapat pengaruh yang signifikan antara bauran promosi terhadap kepuasan konsumen.

2. Pada variabel kualitas layanan didapatkan t hitung (10.531) > t kritis (1.971) maka keputusannya adalah $\mathrm{Ho}_{2}$ ditolak dan $\mathrm{Ha}_{2}$ diterima, artinya bahwa secara parsial terdapat pengaruh yang signifikan antara kualitas layanan terhadap kepuasan konsumen.

\section{Uji F}

Uji hipotesis ini bertujuan untuk mengetahui apakah variabel bauran promosi (X1) dan variabel kualitas layanan (X2) secara bersama-sama mempengaruhi variabel kepuasan konsumen (Y) atau tidak. Pengujian tersebut dilakukan dengan cara membandingkan $\mathrm{f}$ hitung dengan $\mathrm{f}$ kritis. Menurut Priyanto (2009) f kritis dapat dicari pada tabel statistik pada signifikasi 0.05 df $1=\mathrm{k}-1$ dan df $2=\mathrm{n}-\mathrm{k}$ ( $\mathrm{k}$ adalah jumlah variabel) kemudian masukan ke cell kosong pada excel ketik $=\operatorname{FINV}(0.05,2,204)=$ 3.04016. Menunjukan bahwa f kritis adalah 3.04016 Dibawah ini menunjukan gambaran hasil dari uji f sebagai berikut :

1. $\mathrm{F}$ hitung $\leq \mathrm{F}$ kritis jadi $\mathrm{H}_{0}$ diterima.

2. $\mathrm{F}$ hitung $>\mathrm{F}$ kritis jadi $\mathrm{H}_{0}$ ditolak.

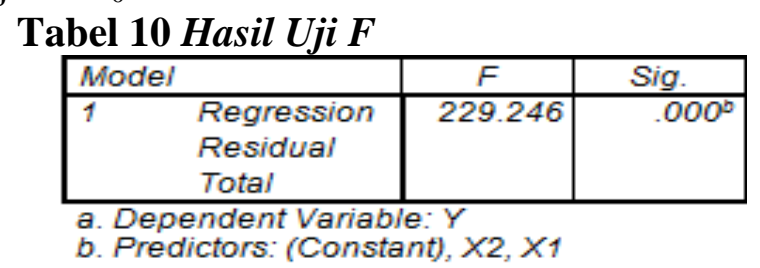

Sumber: Pengolahan data mengunakan SPSS 24

Berdasarkan Tabel 10, F hitung > F kritis $=229,246>3.04016$. Hal ini menjelaskan atau mengindikasikan bahwa $\mathrm{H}_{0}$ tidak di terima, yang mengartikan bahwa variabel bauran promosi (X1) dan kualitas layanan (X2) sebagai variabel independen secara simultan memiliki pengaruh yang signifikan terhadap variabel terikat kepuasan konsumen (Y).

\section{Uji Koefisien Determinasi}

Uji koefisien determinasi merupakan ukuran untuk mengetahui seberapa besar sumbangan pengaruh pada antara variabel bebas terhadap variabel terikat. Berikut hasil uji koefisien determinasi.

Tabel 11 Koefisien Determinasi

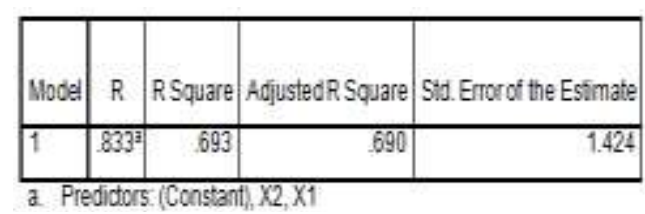

Sumber: Pengolahan data mengunakan SPSS 24

Tabel 11 memperlihatkan nilai $\mathrm{R}^{2}$ sebesar 0,693. Hal ini menunjukan bahwa kepuasan konsumen sebesar 69,3\% dijelaskan oleh variabel bauran promosi dan kualitas layanan, 


\section{National Conference of Creative Industry: \\ Sustainable Tourism Industry for Economic Development}

Universitas Bunda Mulia, Jakarta, 5-6 September 2018

ISSN No:

sedangkan 30,7\% dijelaskan oleh variabel lain yang tidak dimasukkan kedalam penelitian. Hasil ini menunjukan bahwa $\mathrm{R}^{2}$ mendekati satu, sehingga variabel bebas (bauran promosi dan kualitas layanan) secara keseluruhan dapat menjelaskan variabel terikat (kepuasan konsumen).

\section{Analisis Kuat Pengaruh Indikator Menggunakan Nilai Mean}

Analisis indikator Variabel Bauran Pemasaran dengan memakai perhitungan nilai mean yang tertinggi ada pada indikator "Promosi yang dilakukan Go-food menarik “ yaitu dengan item pernyataan BP7. Dengan demikian untuk mitra perusahaan pertahankan dalam memberikan promosi kepada konsumen yang menggunakan Gofood, agar konsumen merasa puas dengan promosi yang terus diberikan. Sedangkan nilai mean terendah ada pada indikator "Promosi melalui sosial media pribadi membuat konsumen tertarik" yaitu dengan item pernyataan Bp16. Dengan demikian untuk divisi marketing untuk lebih sering memberikan promosi lewat sosial media, agar konsumen terbenak untuk mengingatdan menggunakan jasa Go-food itu akan membuat konsumen tertarik.

Analisis indikator Variabel Kualitas Layanan dengan nilai mean yang tertinggi ada pada indikator "Restaurant yang bekerjasama dengan Go-food banyak" yaitu dengan item pernyataan KL11. Dengan demikian dapat disimpulkan perusahaan harus lebih meningkatkan dan mempertahankan untuk restaurant yang mau bekerjasama dengan Go-food, karena dengan begitu konsumen akan merasa puas dengan jasa Gofood. Sedangkan nilai mean terendah ada pada indikator "Driver Go-food memberikan perhatian kepada konsumennya" yaitu dengan item pernyataan KL8. Dengan demikian dapat disimpulkan untuk para driver Go-food lebih ditingkatkan kembali untuk memperhatikan pesanan para konsumen .

Analisis indikator Variabel Kepuasan Konsumen dengan nilai mean yang tertinggi ada pada indikator "Go-food memberikan pelayanan sesuai yang dijanjikan" yaitu dengan item pernyataan KK1. Dengan demikian dapat disimpulkan untuk perusahaan memberitahu kepada driver Go-food lebih semangat dan teliti dalam memberikan pelayanan yang di inginkan konsumen, agar konsumen terus pecaya dengan hasa Go-food. Sedangkan nilai mean terendah ada pada indikator "Go-food memberikan pelayanan yang baik kepada konsumen" yaitu dengan item pernyataan KK2.

\section{KESIMPULAN DAN IMPLIKASI Simpulan}

Berdasarkan hasil dari penelitian yang telah dilakukan dalam menguji pengaruh bauran promosi dan kualitas layanan terhadap meningkatnya kepuasan konsumen Gofood yang dibantu oleh data yang didapatkan dan diolah dengan menggunakan alat analisis statistik dan juga berdasarkan hasi penelitian yang telah dijelaskan diatas, maka dapat disimpulkan sebagai berikut:

1. Variabel bauran promosi berpengaruh signifikan terhadap kepuasan konsumen Gofood.

2. Variabel kualitas layanan berpengaruh signifikan terhadap kepuasan konsumen Gofood.

3. Secara simultan, variabel bauran promosi dan kualitas layanan berpengaruh signifikan terhadap kepuasan konsumen Go-food. 


\section{National Conference of Creative Industry: \\ Sustainable Tourism Industry for Economic Development}

Universitas Bunda Mulia, Jakarta, 5-6 September 2018

ISSN No:

\section{Keterbatasan Hasil Penelitian}

Dalam melakukaan penelitian ini, keterbatasan yang peneliti alami adalah:

1. Tanggapan responden hanya di tujukan kepada orang yang mengetahui dan pernah menggunakan jasa Go-food di aplikasi Gojek.

2. Penelitian ini menggunakan aplikasi google form untuk mengisi pernyataan. Sehingga tidak menutup kemungkinan terdapat unsur subjektivitas dalam penelitian ini atau peneliti tidak bisa memastikan apakah quesioner di isi sendiri atau di isi peneliti.

\section{Implikasi Manajerial}

Analisis indikator Variabel Bauran Pemasaran menunjukkan dibutuhkan peningkatan pada aspek platform promosi melalui sosial media pribadi yang ternyata memiliki pengaruh "membuat konsumen tertarik". Dengan demikian, divisi marketing dituntut untuk mengembangkan platform promosi media sosial agar konsumen terbenak untuk mengingatdan menggunakan jasa Go-food itu akan membuat konsumen tertarik. Selain itu, analisis indikator Variabel Kualitas Layanan menunjukkan dibutuhkan peningkatan perhatian dari driver Go-food kepada konsumen. Dapat dilakukan kegiatan pelatihan-pelatihan guna meningkatkan kualitas layanan khususnya dalam meningkatkan perhatian mitra Go-Food pada konsumen. Yang ketiga, dari analisis indikator Variabel Kepuasan Konsumen terlihat bahwa Go-food dituntut untuk memberikan pelayanan yang lebih baik kepada konsumen agar semakin puas dan loyal.

\section{DAFTAR PUSTAKA}

Arif. (2017). "Pengaruh Harga, Promosi Dan Kualitas Pelayanan Terhadap Kepuasan Pelanggan Dan Loyalitas Transportasi Ojek Online Go-jek (Studi Kasus Pada Mahasiswa Feb Usu)". Jurnal Ilmu Manajemen. Vol. 20 No.5.

Avin, R (2018) "Promo Go-food Melimpah Di Hari Kuliner Nasional". [online]. Diakses pada 16 Maret 2018 dari https://halallifestyle.id/finance/promo-go-foodmelimpah-di-hari-kuliner-nasional.

Dianti. (2017). "Pengaruh Harga, Pelayanan dan Promosi terhadap Keputusan Penggunan Jasa Angkutan Gojek Pada Mahasiswa Jurusan Pendidikan Ilmu Pengetahuan Sosial Uin Syarif Hidayatullah Jakarta". Jurnal Ilmu Pengetahuan Sosial. Vol. 17 No. 2.

Eka, R. (2017) "Beberapa Insight Menarik iprice tentang Bisnis E-commerce Indonesia". [online]. Diakses pada 15 Maret 2018 dari https://dailysocial.id/post/beberapa-insight-menarik-iprice-tentang-bisnis-ecommerce-indonesia/.

Hamid, S. (2018) "Ekonomi Digital di Indonesia: Raksasa Asia Tenggara". [online]. Diakses pada 15 Maret 2018 dari https://investigasi.tempo.co/193/ekonomidigital-di-indonesia-raksasa-asia-tenggara

Hartatik. (2017). "Pengaruh Kualitas Pelayanan, Harga dan Promosi Terhadap Customer Loyalty Dengan Customer Satisfication Sebagai Variabel Intervening 


\section{National Conference of Creative Industry: \\ Sustainable Tourism Industry for Economic Development}

Universitas Bunda Mulia, Jakarta, 5-6 September 2018

ISSN No:

(Studi Kasus Pengguna Go-jek Di Kota Semarang)”. Jurnal Ilmu Manajemen. Vol. 8 No. 4.

Indriantoro, N dan Supomo, B. (2012). Metodologi Penelitian Bisnis Untuk Akuntansi dan Manajemen. Yogyakarta: BPFE.

Khusaini, A. (2016). Analisis Kualitas Pelayanan terhadap kepuasan Konsumen di SPA Club Arena Yogyakarta. Skripsi Prodi Ilmu Keolahragaan, UNY.

Kotler, P and Amstrong. (2012). Bauran Promosi. Jakarta: Salemba Empat.

Kotler, P and Keller, K.L. (2009). Manajemen Pemasaran. Jakarta: Erlangga.

Malhotra, K.N. (2010). Marketing Research. $6^{\text {th }}$ Edition. USA: Prentice Hall, Inc.

Michael N. Lontoh. (2016). "Analisis Pengaruh Bauran Promosi Terhadap Keputusan Pembelian Mobil Toyota Pada PT. Hasjrat Abadi Manado Cabang Tendean Manado". Jurnal Manajemen, Fakultas Ekonomi dan Bisnis. Vol 16 No. 1.

Mulyatiningsih, E. (2012). Metode Penelitian Terapan Bidang Pendidikan. Bandung: Alfabeta.

Priyanto, D. (2009). Mandiri Belajar Dengan Program SPSS. Jakarta Selatan: Penerbit Buku Kita

Sangadji, E.M., dan Sopiah. 2013. Prilaku Konsumen: Pendekatan Praktis Disertai:Himpunan Jurnal Penelitian. Yogyakarta: Penerbit Andi.

Sugiyono. (2012). Metodologi Penelitian Kuantitatif, Kualitatif dan R\&D. Bandung: CV Alfabeta.

Sulaiman, (2012) Pengaruh Bauran Promosi (Promotional Mix) Terhadap Peningkatan Penjualan Pada Sophie Martin Bussines Centre Rina Sari Dewi Pekanbaru. Skripsi, Universitas Islam Negeri Sultan Syarif Kasim Riau.

Sunyoto, D. (2011). Metodologi Penelitian Ekonomi. Cet. 1. Yogyakarta: CAPS.

Tjiptono, C. (2012). Manajemen Pemasaran. Yogyakarta: Andi. (2011). Manajemen Pelayanan. Yogyakarta: Gava media. 